\title{
Problems with the Drawing a State Border along the River Psou Section
}

\author{
Dali Nikolaishvili ${ }^{1,}$,, Revaz Tolordava ${ }^{2}$, Davit Sartania $^{3}$, Lali Kutateladze ${ }^{2}$ \\ ${ }^{1}$ Department of Geography, Faculty of Exact and Natural Sciences, Tbilisi State University, Tbilisi, Georgia \\ ${ }^{2}$ Department of Geography, Faculty of Natural Sciences and Healthcare, Sokhumi State University, Tbilisi, Georgia \\ ${ }^{3}$ Museum of TSU, Tbilisi State University, Tbilisi, Georgia
}

Email address:

dali.nikolaishvili@tsu.ge (D. Nikolaishvili)

\section{To cite this article:}

Dali Nikolaishvili, Revaz Tolordava, Davit Sartania, Lali Kutateladze. Problems with the Drawing a State Border along the River Psou Section. Earth Sciences. Special Issue: Modern Problems of Geography and Anthropology. Vol. 4, No. 5-1, 2015, pp. 60-67.

doi: $10.11648 /$ j.earth.s.2015040501.21

\begin{abstract}
The work deals with analysis of problems with the drawing a state border along the River Psou Section. The problem is difficult to solute due to the modern complex geopolitical situation in the Caucasus region, wrong decisions of the past and historical documents and cartographic sources with the inadequately shown reality. One of the major hampering factors is the state practice of territorial spacing of the former Soviet republics implying giving the state borders of a country having lost its independence a status of administrative borders. The main purpose of the study is to give the geographical-cartometry analysis of the historical transformations of the River Psou section of the Georgian state border. A lot of various cartographic sources, governmental Resolutions, historical and statistical data also were used as the basis of the study. Different factors as one of the main factors determining the historical change of this section of state border are discussed in the paper. The research was conducted in different main directions: the evaluation of historical transformations of state border throughout of XIX-XX centuries and in modern times, factors hampering the regulation of the state border, issue of the territorial belonging of village Aibga, etc. In order to study these issues have used different methods as well as GIS-technologies. The main results of research are determination of some issues connected with state border along the river Psou section: 1) the frequency of historical transformations; (2) the major factors causing this historical transformations; (3) incompliance between the existing cartographic sources and governmental resolutions in relation to the registration of all five districts of village Aibga, (4) the facts of incorrect depiction of the territorial belonging of the river Psou section in the XX-century scientific and statistical sources.
\end{abstract}

Keywords: State Border, River Psou, Georgia, Delimitation, Demarcation

\section{Introduction}

Historically, the regulation of state borders was always one of the major concerns for any state, as this issue was always associated with changing the territory of the countries, existence of the nations and changes to the national language and culture. Therefore, in the history of mankind, the issue of a state border has always been the source of the problem arising between the states. This question is particularly urgent for the countries, like Georgia, which on the one hand, for centuries, had to protect its territory on the background of the permanently changing borders and is in a hard geopolitical situation at present, on the other hand.

The demolition of the Soviet Union and origination of the sovereign states in the South Caucasus in the 1990s puts the question of delimitation and demarcation of the state borders in the Post-Soviet space on the agenda. Peaceful and timely resolution of this issue is hampered by a number of circumstances: modern complex geopolitical situation in the region, wrong decisions of the past and historical documents and cartographic sources with the inadequately shown reality. One of the major hampering factors is the state practice of territorial spacing of the former Soviet republics implying giving the state borders of a country having lost its independence a status of administrative borders. Despite the fact that the allied republics of the Soviet Union (including the Georgian SSR) were considered sovereign republics, no documents about the borders between them existed and no 
relevant marking was ever undertaken. Consequently, this issue is depicted wrongly and inadequately in large-scale topographic maps.

Frequent changes of the territorial belonging of the areas along the state border of Georgia are associated with unfair plotting of the administrative borders during the Soviet period, different interpretations of the data found in various sources, non-delimited and non-demarked border and its location in an uncontrolled area, etc. In this respect, one of the important factors is also cartographic sources. Among other reasons, one can name inaccuracies and inadequate depiction of reality in the cartographic sources. Consequently, the analysis of the contour of the state borders given in the old cartographic sources and examination of their compliance with the governmental resolutions seems much more important. The fact of "Aibga section" of the state border being a certain hot political point till present needs the designing of a single electronic base of cartographic sources and their thorough analysis. In this respect, the present work is a step forward.

Besides, not all the perimeter of the state border of Georgia is delimited or demarked, but only a 275-km-long Georgian-Turkish border, as a "heritage" of the state border between Turkey and the Soviet Union.

Despite its political significance, the cartographic-geodetic basis to organize the state borders has not been developed or scientifically proved to date. The list of scientific works dedicated to the resolution of the above-mentioned problem by using the principle of cadastre geo-information mapping, i.e. the principle possible to use to create a system of any spatial and time changes and control and operative response, is very short. It is such deficient methodological base to be blamed for a number of disputable precedents of delimitation and demarcation in modern world, including Georgia [1].

All the above-mentioned issues lead to a number of problems. This is why thorough study and analysis of all surroundings, including the geographical-cartographic problems and development of scientifically substantiated fundamentals are so important to.

Decree No. 59 "On approving the state border management strategy of Georgia" of the President of Georgia of February 4, 2008 states that as a result of the work of the State Commission for Delimitation and Demarcation, $65 \%$ of the border sections with Armenia and Azerbaijan each and 40\% of the section of the border with Russia are agreed (delimited) [2]. Therefore, the share of the unresolved and disputable sections of the total perimeter of the state border of Georgia is quite high. In this respect, the question is particularly severe with the River Psou section of the Georgian-Russian state border. Historically, this section of the state border has been subject to significant changes, unlike other sections of the border with Abkhazia. The reason is the Great Caucasus mountainous region and cliffy massifs erected off some of its sections, as well as areas covered with eternal snow and glaciers. It is historically known that this natural border played an extremely significant role in protecting the country against the main purpose of the study is to give the geographical-cartometry analysis of the historical transformations of the River Psou section of the Georgian state border.

\section{Research Methods and Initial Data}

Various cartographic sources were used as the basis of the study:

- The Verst maps of the Caucasus and adjacent areas of the XIX century, drafted by the Topographic Department of the Military District Staff of the Caucasus based on the geodetic, topographic and astronomic works accomplished in the region. These maps are of different scales and were drafted in the old Russian metric system (1, 2, 3, 5, 10, 20, 40-verst options);

- A series of historical maps [3] showing the territory and borders of Georgia in different historical epochs;

- The Soviet topographic maps published in different years (scaled 1:100 000 and 1:25 000) showing the relief, natural components, infrastructure, supporting geodetic network, etc. in details; the maps published or updated in different years $(1940,1960,1970,1980)$ often give different contours of the state borders;

- The political-administrative maps published in the Soviet period.

The accuracy and completeness of the maps allow resolving the study objectives with a high degree of accuracy.

The study is also based on the analysis of the governmental resolutions and international agreements of different periods, in particular, on the information about the state border of Georgia given in these documents.

In the study were used historical-genetic, historical-comparative, cartographical methods as well as GIS-technologies.

\section{Study Area}

The northern and north-western sections of the state border of Georgia were formed as a result of a long historical relationship with the neighboring peoples and it mostly ran along the natural boundaries. It is these sections of the state border of Georgia mostly along the central high-mountainous section of the Great Caucasus, having been subject to the least historical variations, where eternal snows and glaciers and cliffy massifs lie as an almost continuous line. Historically, this natural boundary played a major role in protecting the country against invaders from the north. However, even the perimeter of the said border used to change and as a result, even to date we see disputable sections of the state border.

The River Psou section of the Georgian state border runs for $57 \mathrm{~km}$ along the River Psou, which is the Georgian-Russian border. The River Psou heads from mount Agepsta (3257 m asl) on the main Caucasioni watershed ridge and flows through a deep and woody gorge. In its lower reaches, the river flows across the Black Sea coastal plain and into the Black Sea near settlement Gantiadi (Georgia).

The Main Ridge of Great Caucasus is stretched between 
mount Agepsta and a nameless peak (between the Rivers Gvandra and Dalari) known as the Great Caucasus of Abkhazia. On its western part, the watershed of the Rivers Mzimta and Psou is presented by Atsetuk ridge. Mount Agepsta located along the border of Krasnodar krai (the highest-level administrative unit) is erected off this ridge. This section of the border is quite low; however, eastwards, its absolute height increases gradually and the ridge has more and more cliffs. There are also small glaciers at some places. The vegetation cover is mostly presented by alpine grasses, sub-alpines and very small fragments of beech-and-fir forests The border reaches Akhukdari Pass (2072 m asl) connecting the gorges of the Rivers of Lashipse (flowing into Ritsa Lake) and Mzimta (flowing into the Black Sea at the City of Adler, Russia). Here ran a tourist route from Resort Avadhar (Georgia) to village Krasnya Polyana (Russia).

There are some settled areas along the river, with settlement Gantiadi and villages Salme, Sulevo, Salkhino, Tsabliani and Aibga located on the territory of Georgia and villages Vesioloye, Nizhnee Shilovka, Verhnee, Shilovka and Ermolyovka located on the territory of Russia. Most of these villages are located either on the right, or left bank of the River Psou. Only village Aibga is located on the both sides of the River Psou. Village Aibga is located in the basin of the upper reaches of the River Psou, on the both sides of the river. It covers 5 districts, including 3 districts on the left side of the River Psou (Georgia, Gagra municipality) and 2 districts located on the right side of the River Psou (Russia, Adleri region). Such state of affairs has made village Aibga with all its five districts covering 16 ha one of the "hottest points" of the state border of Georgia [4].

The village can be reached, both, across the Psou gorge and the Bzipi gorge. The road running from the Black Sea coast to Resort Avadhara folks westwards and runs along the northern part of Gagra Ridge. In respect of tourism, it is a very interesting route with forests growing on the slopes, subalpine and alpine meadows and remains of old (Quaternary) Glacial Age. All this makes the local nature picturesque.

\section{Main Results}

\subsection{Factors Hampering the Regulation of the State Border}

Regulation of the state border of Georgia depends on a number of factors. They can be considered in different contexts. In respect of time, there are historical and modern factors hampering the peaceful regulation of the state border of Georgia, while in respect of content, we see various political, economic and geographic-cartographic factors. However, such grouping is conventional. In addition, if considering the historical trends of the transformations of the state border of Georgia and present political situation in the Caucasus region, it is clear that all the above-listed factors are political in nature, i.e. they are caused by political aspirations.

The demolition of the Soviet Union and origination of the sovereign states urgently put the question of delimitation and demarcation of the state borders in the Post-Soviet space on the agenda. Peaceful and timely resolution of this issue is hampered by a number of circumstances. One of the major hampering factors was the domestic function of territorial demarcation of the allied Soviet republics and giving the state borders the status of administrative borders right from the outset. Despite the fact that the allied republics of the Soviet Union were considered sovereign republics, there were no documents concluded demarking the borders between them and no relevant marking was ever made.

At the beginning of XX century, after Russia conquered the Caucasus and the new administrative division was done consequently, the borders of Georgia were ranked as province borders, and after the establishment of the Soviet authority the borders of Georgia were given the function of the administrative borders of the Russian Federation and Georgia. The only positive thing done in that period in this respect was the adoption of a single act regulating the legal status of the borders between the Republics [5].

The source of stress between Georgia and the Russian Federation, in addition to the national extremism in North Caucasus, is still the failure of international legal registration of some sections of the state border. This not only strains the communication between the nations, but is also a threat to the territorial integrity of Georgia.

\subsection{Border Transformations in the XIX-XX Centuries}

The territorial division in the XIX century was subject to a number of variations followed by the transformation of the territory and borders of the country. At the end of the XIX century, the territory of Georgia included Tbilisi and Rustavi Provinces and Karsi District (Fig. 1). There were three territorial units of Kutaisi Province (Sokhumi Okrug, Lechkhumi and Oni Uezds) and five territorial units of Tbilisi Province (Gori, Dusheti, Tianeti, Telavi and Signagi Uezds) located along the Georgian-Russian border. From the Russian side, these territorial units were bordered by Tergi, Kuban and Daghestan Districts, as well as Black Sea Okrug [3; 6]. To present days, the then-time Georgian-Russian border has been subject to a number of transformations, mostly at the expense of the territorial losses Georgia. An exception is the north-western area of then-time Georgian border (left bank of the River Psou and some sections of the west branches of Gagra Ridge), being a part of the Black Sea Okrug adjacent to Georgia in that time.

After the demolition of the Russian Empire, the sovereign states, including Russia and Georgia, faced the problem of regulating the borders of the former Empire. The state borders of the independent countries of the Trans-Caucasia were fixed based on the administrative division of the Russian Empire, which never observed any ethnic principles, but on the contrary, served the purpose of multinationality. This was the main idea of the empirical police [7]. 


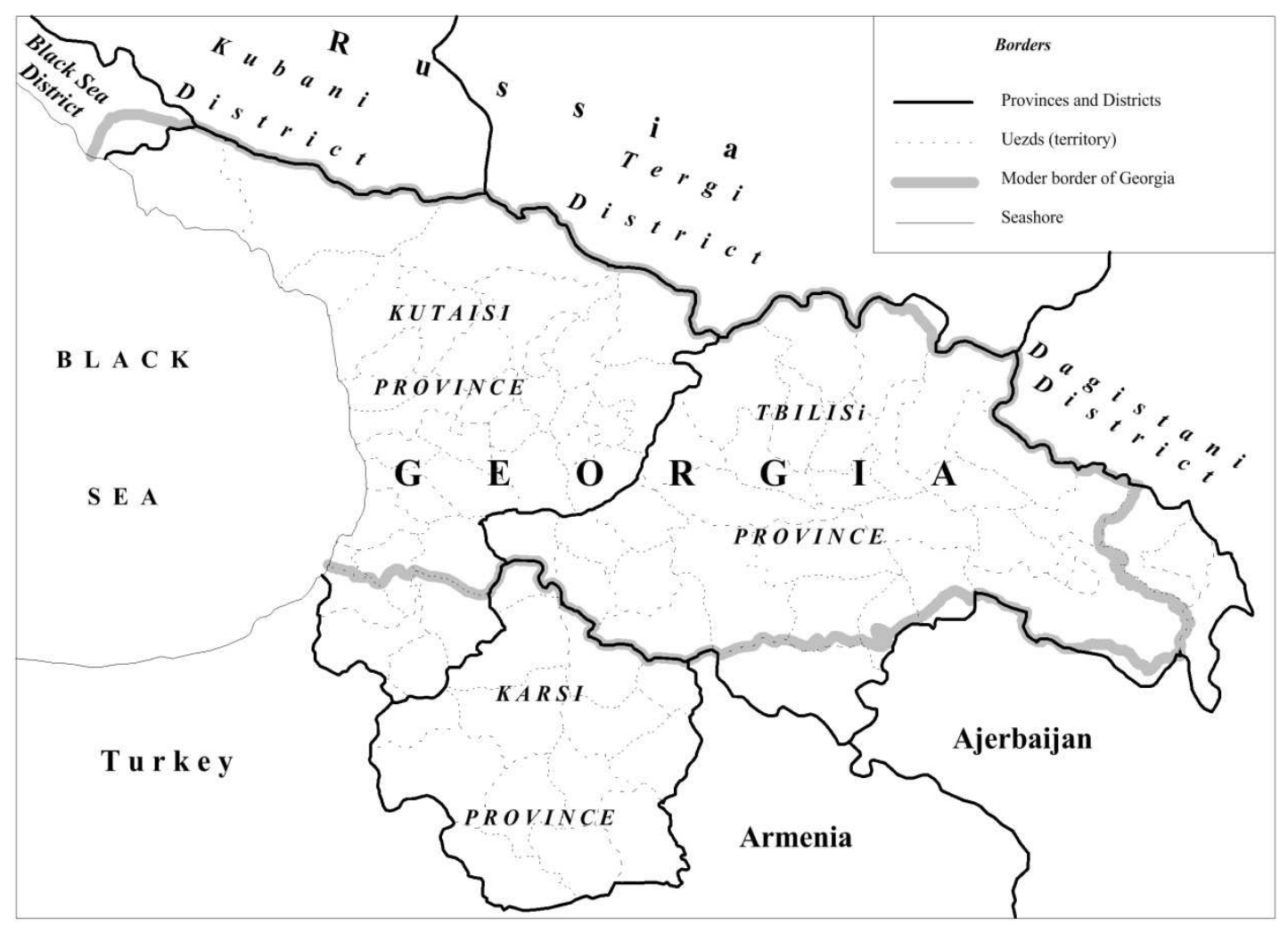

Figure 1. Georgia in a Russian Empire (end of the XIX c.).

Under the Peace Agreement between the Russian Soviet Federal Socialist Republic (RSFRS) and Democratic Republic of Georgia (of 07.05.1920), Russia recognized the "Identity and independence of the State of Georgia" and willfully waived all its rights usurped by it by violating the Treaty of Georgievsk (1883) and abolishing Kartli-Kakheti Kingdom. Under article 3 of the Agreement, the border started on the Black Sea, at the confluence of the River Psou, followed the river up to Mount Asakhcha (2315,2 m asl), reached Mount Agepsta and by running along the Main Ridge of the Greta Caucasus, followed the northern border of the Black Sea Okrug, Kutaisi and Tbilisi Provinces, the territorial units included in the former Russian Empire. From this point, the border ran to Zakatala District and by following its eastern side, reached the Armenian border. Under article 2 of the same Agreement, all passes along the border were recognized neutral and the armies of the negotiating parties were forbidden to occupy or reinforce them (before January 1, 1922). The neutralization zones of the passes were fixed calculated for the distance of 5 versts in both directions from the border point. An exception was some passes, e.g. in Dariali gorge, the zone covered the area from Balta to Kobi and it spread from Zamaragi to Oni across Mamisoni Pass [8].

The Agreement envisaged the establishment of a special border committee staffed with equal number of members from each signatory state with its work to be described in a special agreement, and most importantly, clause 1 of article 3 of the Peace Agreement fixed the border between Russia and Georgia as the state border.

On February 25, 1921, Russia annexed the Democratic
Republic of Georgia and established the Georgian SSR on its territory. As a result, the territorial integrity of Georgia was disturbed and the country lost 20 thousand sq.km of its territory [9]. The northern border of Georgia was not an exception, either. Then-time border of the Republic started on the territory of Abkhazia, at the confluence of the River Kholodnaia Rechka (the Bagrishta, now Tsivskaro), in Pilenkovo Region (presently, town Gantiadi). The new border took away $380 \mathrm{~km} 2$ of the territory of Georgia and the territory from the present-day Gantiadi up to the confluence of the River Psou occurred beyond Georgia.

Recognition of the Soviet Socialist Republic of Abkhazia (on 04.03.1921) and the declaration of the Independence of Abkhazian SSR issued in the same year disturbed the territorial integrity of Georgia on a temporal basis. This incompliance was corrected based on the Union Agreement concluded between the Georgian Soviet Socialist Republic and Abkhazian SSR with the entry of Abkhazia in Georgia (on 13.12.1921).

The years of 1924-1929 saw several changes to the border between the RSFRS and Georgian SSR, in particular, along the border of Abkhazian SSR and the Black Sea Okrug (by the decision of the Central Executive Committee of the USSR, Pilenkovo community from the subordination of Russia moved to Georgia twice (on 31.10.1924 and 31.12.1928), and vice versa, from Georgia to RSFRS (on 19.03.1926). In 1928, the Central Executive Committee of the USSR adopted a resolution about including Pilenkovo community in Abkhazia and established a Parity Commission to realize the decision in practice (on 31.12.1928). However, only 4 village councils 
(Mikeliripshi, Pilenkovo, Salme and Kristepore) were given to Georgia, while the fifth one, Aibgi village council remained a part of the Black Sea coastal okrug, Sochi region. Its territory is shown in the map, and the location of the border between the RSFSR (The Russian Soviet Federative Socialist Republic) and Georgia along this section, by the resolution of the Supreme Council of the USSR, was fixed as follows: "within the borders of the colonization fund south of village Aibga,.. the border after Aibga shall continue across the River Psou." [8].

The section of village Aibga is one of the best examples of an incorrect drawing of a state border. This village located on the Georgian-Russian border was divided into two: the part of the village on the left side of the river Psou gorge became a part of Georgia, while another part of the village was made a part of Russia (Fig. 2). In 1992, the Russian armies allowed Abkhazia the part of village Aibga "due" to Russia; later, Russia required allowing $160 \mathrm{~km} 2$ area to it, and an intergovernmental commission was established for this purpose. The commission was charged with solving the issues of the border demarcation and delimitation; however, at present, this section of the Georgian state border is still a disputed territory between Russia and self-recognized Abkhazia.

In 1943-1944, significant changes were made to the territory along the northern border of Georgia resulting in the forced resettlement of the north-Caucasian indigenous population to Central Asia followed by the distribution of the "due" areas between Georgia and Russia.

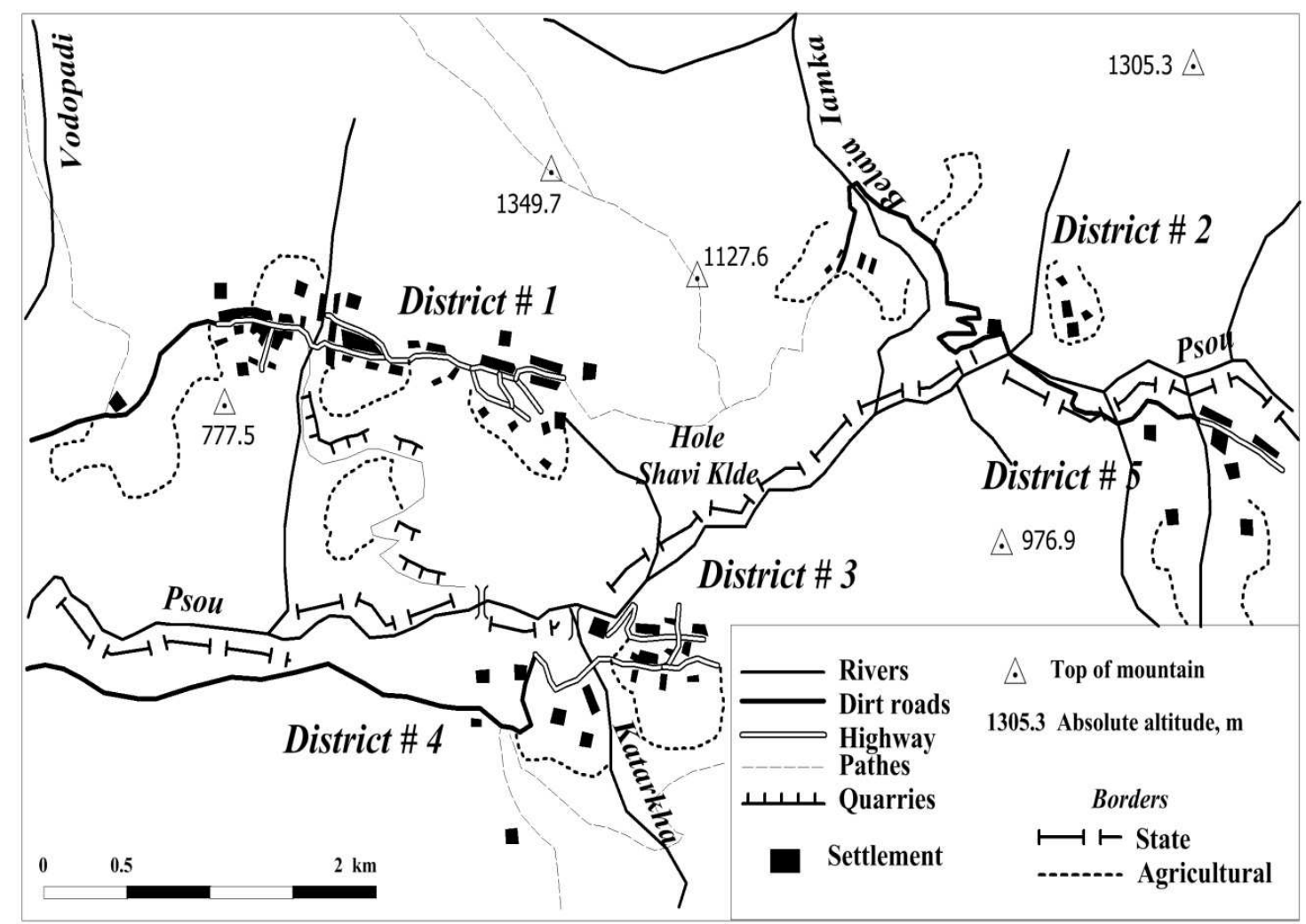

Figure 2. Location of Village Aibga on the Border of Georgia and Russsia.

\subsection{Transformation of the State Border in Modern Times}

It is a known fact that permanent implications in the Georgian-Russian border zone are the result of the strategic plans of the Russian Federation. The events after the demolition of the USSR and the wish of the Russian government to retain its control over the south Caucasus led to the origination of the separatist regions. The sections of the Georgian-Russian border in the territories of Abkhazia and Tskhinvali turned out beyond the control of official Tbilisi. Since 2004, the Russian government has understood that Georgia's aspiration to NATO was irreversible and Russia became more active wishing to expand and annex the border regions of Georgia.

\subsection{Issue of the Territorial Belonging of Village Aibga}

Village Aibga is mentioned in many scientific-geographical literary sources as a former village. However, some modern Russian sources name village Aibga located on the left bank of the River Psou as a settled area what cannot be proved if considering two most recent general censuses of the population of Georgia [10]. Neither administrative-territorial division of Georgia (1961, 1966, 1987), administrative-territorial division of Abkhazia [11], nor orthographic dictionary of the geographical names of Georgia [12] do mention village Aibga.

Today, the boundary territory of village Aibga is made disputable between Russia and so called Abkhazian 
government and has been the subject of dispute of the intergovernmental commission more than once. In addition to a number of circumstances, the resolution of the issue is hampered by the historical reality inadequately shown in the cartographic sources.

The analysis of different maps [3] showed that the left side of the river Psou and "Aibga section" of the state border were a part of Egrisi (Kolkheti) kingdom since the VI-III cc B.C. However, it also should be noted that these territories were subject to permanent transformations, particularly in the last centuries (Fig. 3). From the VI-III cc. B.C., the state border followed the main watershed ridge of the Great Caucasus, but unlike the modern border, it did not descend into the gorge of the upper reaches of the Psou (as it is now), but followed the main ridge much farther in the west, presumably, from Mount Avadhar $(2960.7 \mathrm{~m})$ to mount Pishta $(2867 \mathrm{~m})$. In the following historic epochs, the territorial belonging of village Aibga used to change on a periodic basis; however, for most of the history, it was a part of the Georgian state or Abkhazia, the princedom-kingdom/vicariate of Georgia [4]. The transformations of "Aibga section" of the state border became intense in the XIX-XX centuries on the background of the political battles.

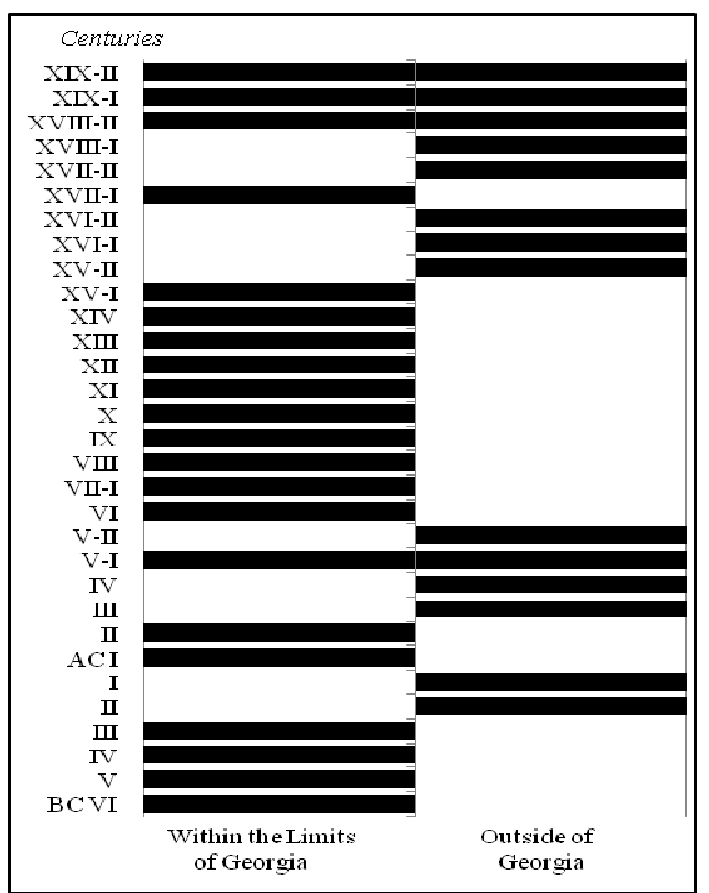

Figure 3. Issue of the Territorial Belonging of Village Aibga in Different Historical Eepochs.

Almost all cartographic sources of the XIX century made in Russian, French, English or German languages [13, 14, 15, 16, $17,18,19,20,21]$ show that "Aibga section" is not a part of Georgia. An exception is some maps, e.g. a German map published in 1808 [22], with the territory of Abasses covering a large area from Taman P eninsula to Ilori (Ochamchire District at present). The study object belongs to Abkhazia according to one of the maps of 1857 [23]. The map gives Aibga as a small territorial unit, which is not a settled area.
Until 1877, Aibga tribe lived in several villages. This is evidenced by the records made by P. Tornau, a Russian officer and an author of the documentary-literary work: "...Achipsou, Aiboga and Chuzhgucha in the upper reaches of Mdzimta, Psou and Mtsa. The last four settlements were known to the Circassians with one name of Medovey. Marshanias, divided into two trends of Bogorkanipovs and Masips, were also dominant among them..." [24]. However, the said map does not clearly show the territorial belonging of Aibga.

From 1866, when the Caucasian wars were over, the cartographic sources still showed the study object beyond the borders of Georgia [25, 26, 27, 28]. The reason was Chernomorsk Okrug formed on this Black Sea coastal territory, which was included in Kuban province. The okrug spread from Tuapse to the gorge of the lower reaches of the River Bzipi [29], and in 1896-1918, it was made Chernomorsk Province [30]. However, even to date, some cartographic sources fail to adequately show the reality. For example, as per the map of Caucasus of 1869 [31, 32], Chernomorsk Okrug in south-east reaches not the gorge of the river Bzipi, but watershed of glaciers Khashupse and Kholodnaya Rechka near Gagra.

In 1901, the Caucasian map (40-verst, scale: 1: 1,680,000) showing the state borders in 1801-1813 [28], the territories of Abkhazia and Zemo Svaneti are beyond the territory of Georgia and as independent units, are included in the lands of mountain people.

"Aibga section" of the state border was particularly intensely changed in the first half of the XX century, again in connection with the political battles. The first change in the $\mathrm{XX}$ century was associated with the Emperor's Decree of 1904 [33]. As this document shows, a district of a climatic station in Gagra was isolated from Sokhumi Okrug and was made a part of Sochi Okrug (Chernomorsk province), i.e. the border of Georgia shifted south-east. Consequently, in the map of Kuban oblast [34, 35], all the "Aibga section" was a part of Russia. Even Sokhumi Okrug was isolated from Kutaisi province and made a part of Sochi Okrug; however, it seems as "an independent unit" in the said map, as it does not belong to either Chernomosrk, or Kutaisi province. Another map published in the same year, even the sector of Gagra was isolated from Sokhumi Okrug and made a part of Sochi Okrug.

The changes of "Aibga section" of the state border reached the peak in 1917-1929. For this 12-year-long period, the border changed for eight times. In particular, from 1918, the border ran along the River Psou (two districts of the village were a part of Russia and 3 districts were a part of Georgia), from 1919 the border runs along the River Bzipi, from 1920 it runs again along the River Psou, to Mount Akhakhcha (Mount Kamerin-Depa, 1967.5 m, the watershed of the Rivers Psou and Pkhista across Tepebash Ridge [5], from 1921 the border runs along the River Bagripshta, the same as Kholodnaya (the river north-west of the city of Gagra, making "Aibga section" a part of Russia). In 1924, the situation changed again and Pilenkov community was a part of Georgia [36], and from 1926 it was a part of Chernogorsk Okrug (Russia) [37]. 
Drafting the border along the River Psou under the Agreement of 1920 was considered a great success of Georgian diplomacy, as "the major part of the territorial requirements of Georgia were met and even went beyond the borders of Kutaisi Province and Sokhumi Okrug to cover the territory of Gagra, which was a part of Sochi Okrug of the Black Sea Province before." [38. p. 10].

Village Aibga was a part of Georgia and was located on the territory of the modern Gudauta District, but in 1921, when Soviet Russia annexed our country, village Aibga occurred within the limits of Sochi region. In 1928, under the resolution of the Demarcation Committee, the border between the RSFSR and Georgia was drawn along the river Psou. The Committee used the advantage of the Russian ethnos to the Indigenous (Abkhaz) population, ignored the principle of historical equity and appropriated village Aibga located on both sides of the river Psou to the Russian Federation. The resolution cited an absolutely groundless view saying that the given political decision was motivated by the economic and cultural interests of the population. Therefore, at present, only a small part of village Aibga, or to be more exact, of the site of former village is found within the limits of Georgia.

A clear picture of the changes of those years is given by different-scaled maps in Georgian and Russian languages. For example, the maps dated before 1928 show village Aibga as a part of Russia, while in 1928 [39], Mikeliripshi, Pilenkov, Salme and Kristopher village councils were handed over to Georgia and the fifth village council of Aibga (the fifth region of Aibga) was a part of Sochi region of the Black Sea Okrug [40]. This Resolution of the Presidium of the Supreme Council of the USSR reads: "...south of the given village (village Aibga, the settled area), within the limits of the colonization fund, marked through recognition and plotted in the forestry map of Sochi region of the RSFSR. The border beyond past Aibga is to be continued along the river Psou." However, as per the maps published in 1928 and 1929 [41, 42], all the "Aibga section" is located beyond Georgia.

Another example of incorrectly drawn state border on the map is the cartographic sources of 1929. From 1929, under the resolution of the Council of People's Commissars by virtue of Stalin's Special Resolution [44], Pilenkov sub-region was made a part of Georgia. However, the maps of the period after 1929, including the ones in the Georgian language, show the border as it was in 1928. For example, the map published by the Institute of Cartography of Georgia in 1932 (under the leadership of Prof. Al. Javakhishvili and assistant S. Tskhakaia) shows the border following the middle reaches of the River Psou and reaching Mount Akhakhcha, as this was fixed in 1904. As per the map of 1931-1932 [45, 46, 47], also published under the leadership of Prof. Al. Javakhishvili, the border follows the watershed of the rivers Psou and Mzimti. Consequently, all five districts of village Aibga belong to Georgia. It is unclear which resolution was used as the basis for this section of the state border being differently plotted in the maps of the same period.

This was not done by virtue of any resolutions, if not considering the events taking place in the 2000s' concerning the boundary dispute with "Aibga section" and distribution of the Black Sea marine space between Russia and so called Abkhazian government.

\section{Conclusions}

The accomplished study identified the following facts:

- The frequency of historical transformations of "the River Psou section" of Georgian-Russian state border and major factors causing them;

- Incompliance between the existing cartographic sources and governmental resolutions in relation to the registration of all five districts of village Aibga as a part of Russia;

- The facts of incorrect depiction of the territorial belonging of the river Psou section in the XX-century scientific and statistical sources;

- Fact of appropriating the certain territories of Georgia to Adler region in the Soviet period for economic purposes, though in fact, with political ranking.

Thus, the analysis of old cartographic sources (dated by the end of the XIX century and by the beginning of the XX century) evidences that some maps were drafted by ignoring the governmental resolutions. In addition, Psou section of the state border is one of the best examples of the wrong approach and disregard of the geographical factor in the process of delimitation having caused a certain stress of our country with the neighbouring countries more than once. This is why a thorough study of this question is so important.

\section{Acknowledgements}

We thank the colleagues from the Museum of Tbilisi State University and Alexandre Javakhishvili Geographical Society of Georgia, who provided this research by old maps of Georgia and other fund materials that greatly assisted the work.

\section{References}

[1] D. Nikolaishvili, R, Tolordava, "Geographical factr as a bases for research of state borders - an example of Georgia". Journal of Earth Science and Engineering. volume 3, number 10, October (serial number 25), CA, USA, 2013, pp. 701-713.

[2] Resolution \#59, Regulation of Government of Georgia, Tbilisi, Feb. 4, 2008.

[3] Historical Atlas of Georgia (2003). D. Muskhelishvili (Ed.). Tbilisi, Georgian.

[4] D. Nikolaishvili, R. Tolordava, "Geographical-cartometric evaluation of the territorial belonging of village Aibga". Materials of the International Conference dedicated to the 80th anniversary of the Institute establishment "Modern problems of geography", November 7-9, Tbilisi. 2013.

[5] Agreement between Georgia and Russia of May 7, 1920.

[6] Atlas of Georgia . Tbilisi-Moscow, 1964 
[7] R. Gachechiladze. Georgia in Context of World in XX and XXI Centuries, The Main Moments of Political Life, Tbilisi, Bakur Sulakauri Publishing House, Georgian, 2013.

[8] N.V. Pautkina Historical-legislative Analysis of Territorial Delimit of Russia and Georgia (on the onshore place). In: Proceedings of Scientific-Practical Conference, Military Institute of Moscow.

[9] Iv. Javakhishvili. Borders of Georgia. Historical and Modern Period Review (1919). Selected Works, vol. 12. Tbilisi, 1998, pp. 459-513.

[10] Overall census of the population of Georgia, 1989, 2002.

[11] Abkhazian ASSR, administrative-territorial division. Sukhumi, Gosizdat of Abkhazian ASSR, 1953.

[12] Orthographic dictionary of the geographical names of Georgia, Tbilisi, 1987; 2009.

[13] Charte Generale. Lieutenant-General, Ministre et Secretaire d'Etat au Department des Affairs etrangeres Par J.M. Darmet, 1819.

[14] General map of the lands between the Black Sea and the Caspian Sea with the indication of the new border of Russia and Persia, 1819.

[15] General map of Georgia, 1823.

[16] Europe. Partie de La Russie D'Europe, 1827.

[17] Circassian map of 1830.

[18] Map to Ullustrate "Narrative of a Residence in Circassia. James Stanislaus Bell. Esq", 1840.

[19] Karte des Kaukasischen Isthmus - Entworfen und gezeichnet von J-Grassl, 1856.

[20] Map of the mountain people of Trans-Kuban area, source: L. Lule, Tiflis, 1857, 20 Miles in Inch.

[21] General map of the Caucasus, 1858. 30 Miles in Inch.

[22] Charte Landeram Caucasus. I.C.M. Reinecke. Weimar, 1808.

[23] Map of Trans-Kuban..., 1857.

[24] P.P. Tornau (2008). Memories of a Caucasian officer, Moscow, «АИРО-ХХІ», 456.

[25] Map of the Trans-Caucasian region; drafted by Kondratyev, a topographer and staff captain, 1869.

[26] Map of the Black Sea okrug and west Sokhumi okrug, 10 Miles in Inch, 1883.

[27] Map of the Trans-Caucasian region with the indication of borders of 1799; drafted by Tomnyev, lieutenant colonel of the staff of the Trans-Caucasian military okrug of the military-historical department, Tiflis, 1899.

[28] Map of the Caucasian region with the indication of borders of 1801-1813; drafted by Tomnyev, lieutenant colonel of the staff of the Trans-Caucasian military okrug of the military-historical department, Tiflis, 1901, a 40-verst map. Annex to the XVIII west Caucasian department of the Geographic Society; a 10 -verst map.

[29] Resolution of His Emperor's Majesty "On settling the Black Sea okrug and its management”, March 10, 1866.

[30] Supreme command of May 23, 1896.

[31] Map of Caucasian territory, 1869.

[32] Archaeological map of Kuban oblast, compiled by E.D. Felitsin, 1882,20 versts.

[33] Emperor's Decree of December 25, 1904.

[34] Map of Kuban oblast and near Black Sea provinces and a part of Sokhumi okrug; drafted by N.S. Ivanenkov, 1902, 1 verst.

[35] Map of Kuban oblast and near Black Sea provinces and a part of Sokhumi okrug; drafted by N.S. Ivanenkov, 1904, 10 Miles in Inch.

[36] Resolution of the Central Executive Committee of the USSR of October 31, 1924.

[37] Resolution of the Central Executive Committee of the USSR of March 19, 1926.

[38] N. Samkharadze. State border of Georgia - the past and present, Foreign policy and safety program, September, 2012.

[39] Atlas of the USSR, drafted at the cartographic publishing house of NKVD of the RSFSR, author of Introduction: A. Enukidze, Moscow, publishing house of the Central Executive Committee of the USSR, 1928

[40] Resolution of All-Russia Central Executive Committee of the USSR of 31.12.1928.

[41] Transcaucasian Soviet Federative Socialist Republic, 1928, scale 1:3,000,000.

[42] Map of the Georgian SSR, 1929.

[43] Atlas of the USSR, drafted at the cartographic publishing house of NKVD of the RSFSR, author of Introduction: A. Enukidze, Moscow, publishing house of the Central Executive Committee of the USSR, 1928.

[44] Resolution of All-Russia Central Executive Committee of the USSR of 12.04.1929.

[45] The map of the Soviet Socialist Republic of Georgia drafted at the Institute of cartography of Georgia, State Publishing House of Georgia, 1932, scale 1:200 000 .

[46] Instructive physical map of the Soviet Socialist Republic of Georgia drafted and developed at the cartographic study of the Geographic Society of Georgia under the leadership of Prof. Al. Javakhishvili and assistant S. Tskhakaia, 1931-1932, scale $1: 400,000$.

[47] Instructive physical map of the Soviet Socialist Republic of Georgia developed at the Institute of Cartograpy of Georgia, 1932, scale 1:200,000. 